\title{
Using the Theory of Emotional Stakeholders to Experimentally Test the Influence of Proxy Communicators about Organizational Crises in Digital News Reports
}

\author{
A.M. Mason, Ph.D. \\ Associate Professor \\ Department of Communication \\ Pittsburg State University \\ 1701 South Broadway \\ 212C Grubbs Hall \\ Pittsburg, KS 66762 \\ amason@pittstate.edu \\ Elizabeth A. Spencer, M.A. \\ Doctoral Candidate \\ Graduate Teaching Assistant \\ University of Kentucky \\ Kelley Macek, M.A. \\ Doctoral Candidate \\ Graduate Teaching Assistant \\ Ohio University \\ Scripps College of Communication \\ Alison Smith, M.A. \\ Pittsburg State University \\ 1701 South Broadway \\ 213 Grubbs Hall \\ Pittsburg, KS 66762 \\ Stephanie Potter, M.A. \\ Department of Communication \\ Pittsburg State University \\ 1701 South Broadway \\ 213 Grubbs Hall \\ Pittsburg, KS 66762
}

\begin{abstract}
The emergence of new and social media has transformed the way that stakeholders and organizations interact between and amongst each other. Online news consumers are now able to directly respond to crisis news reports by offering their own interpretation, thus expanding the diversity of viewpoints audiences are exposed to (Carpenter, 2010; Springer, 2014). Using the Theory of Emotional Stakeholders framework our study aims (1) to understand how positive and negative user-generated comments in response to online news reports of crisis events impacts audience perceptions of organizational blame; (2) to examine the persuasive effects of user comments when expert or official organizational responses are provided; and, (3) to measure the affective response to online news reports including user comments. Using experimental procedures our findings show that user comments from organizations, faith-holders, and hate-holders contribute to audience evaluations of crisis responsibility, both causal and treatment. Results found that user comments from faith-holders reduced causal responsibility in the intentional cluster compared to the control condition; however, when organizations were facing preventable crises, user comments from faith-holders amplified perceived treatment responsibility. A detailed description of the findings, discussion, limitations and future directions are provided.
\end{abstract}

Keywords: crisis communication, user comments, online news, organizational crisis 
The growth, utilization, and adoption of new and social media have transformed the way stakeholders and organizations interact between and among each other. Publics can presently "connect with organizations and each other in ways that were limited or not possible before," (Hart, 2011, pg. 114). The rapid evolution of new media technology has generated calls from crisis communication scholars for inquiry and study of this emerging domain (Coombs, 2008). Driven to understand the nature of crises in online environments and further inform the corporate crisis communication process, recent models and theories have been posited toprovide new predictive and explanatory insight including the New Media Crisis Communication Model (SiahAnn Mei et al., 2010) and Theory of Emotional Stakeholders (Luomaaho, 2006; 2009).

"For organizations, reputation is everything, and hence what the stakeholders believe and think about the organization, expect from it and say about it to others is likely to affect its reputational assets," (Ndlela, 2019, pg. 77). Ndlela argues that because reputation is a result, not only of interaction between the organization and stakeholders, but also of multiple interactions among stakeholders, then stakeholder orientation should inform all the facets of reputational management in all phases of crisis management. Online news websites have become important forums for analysis because they communicate relevant and timely information to digital audiences and may contribute to the formation of stakeholders' opinion toward organizations.

Poindexter (2012) maintains that online news differs from traditional journalism according to several qualitative attributes including: accessibility, perpetual updating, search-ability, share-ability, comment-ability, link/ease and reliability, contribute-ability, and coolness. Users can actively engage or participate in these forums in a variety of ways such as: (a) clicking on news stories of interest, (b) commenting on news reports, (c) sending in stories or news tips, (d) participating in online surveys/polls, (e) recommending stories or topics, and/or (f) sharing stories through social media networks.

"Posting comments in news articles is currently one of the most popular forms of user participation in online-content generation," (Weber, 2014, pg. 951).Easily accessible content and opportunities to respond to online news reports provides new avenues for understanding media audiences and their interests. We live in an age in which it is now possible to know in real-time the number of times content has been clicked on, shared, commented on, and/or responded to; all are important objective indicators of the level of interest, engagement, and persuasive impact of digital news content.

This study aims (1) to understand how positive and negative user-generated comments in response to online news reports of crisis events impact organizational reputations (2) to examine the persuasive effects of when corporate crisis responses are provided, and (3)to measure the emotional response to online news reports including user comments. To do so we provide a review of literature related to digital news, explain how different reporting styles have previously been found to impact audience perceptions toward organizational responsibility, and use Luoma-aho's Theory of Emotional Stakeholders (TES) as a framework for developing the experimental materials.

\section{Digital News \& Crisis Reporting}

White and Raman (1999) argue that Web 2.0 is the first mass medium to allow an uninterrupted free flow of information, 24/7/365, from source to mass audiences without gate keeping, payment, or filtering. As online and mobile friendly platforms (apps, widgets, etc.) have become more widely used, audiences are increasingly going online for news information (Houston, Hansen, \& Nisbett, 2011). Jenkins (2006) maintains that traditional journalism has adapted to our participatory culture and as a result the rules of engagement between those who produce news content and those who attend to such content have changed.

The manufacturing and production of news content has evolved due to the opportunities provided by new media technology and social media. Recent trends away from traditional journalism now allow users to contribute to multiple stages of the news production process. Consumers of online news information are more involved in the access/observation stage (i.e., receiving the content), and the final stage, interpretation. The interpretation stage occurs after a story is produced and is open for discussion and comment (Domingo et al., 2008; Herminda, 2011). Other important stages such as story selection and how the story is covered, or framed, remain under the control of media professionals.

Herminda (2011) maintains that the interpretation stage is the most accessible for user participation, specifically within the comment section of news stories. Online news consumers are able to directly respond to news stories by offering their own comments, adding insight and interpretation, and expanding the diversity of viewpoints that audiences and stakeholders are exposed to (Carpenter, 2010; Springer, 2014). SiahAnn Mei et al. (2010) previously found that "when crises were reported in online media, more people became aware of them and even helped perpetuate them by circulating them further" (pg. 149). 
Although daily media reports may move past the day-to-day developments of evolving crisis events, the online reports of crises may remain in the public domain and subsequently impact attitudes and perceptions toward an organization's reputation to a wider audience base over an extended period of time. Additional research into the persuasive impact of crisis events reported in digital media environments is needed to more fully understand the anticipated degree of reputational threat that organizations in crisis may face.

\section{Organizational Crisis Responsibility\& Reputation}

Organizational crises vary in their scope, complexity and causality. Situational crisis communication theory (SCCT) incorporates insight from attribution theory as the underlying rationale for linking specific types of crises to specific crisis communication strategies. Based on a compilation of early crisis typologies, Coombs (2007) identifies three crisis clusters to anticipate the degree of reputational threat organizations may face and these include: victimcluster (e.g., events with low organizational responsibility such as natural disasters, rumors, or product tampering), accidental cluster (e.g., events resulting from moderate organizational responsibility such as technical-error accident or technical error product harm), and the intentional/preventable cluster (e.g., events with high organizational responsibility such as human errors or organizational misdeeds). Extant literature has extensively documented the connection between attributions of responsibility and the expected threat to an organization's reputation based on crisis type (Coombs, 2004; Coombs \& Holladay, 1996; Coombs \& Holladay, 2002; Coombs \& Holladay, 2006). In general, SCCT argues when organizations are victims of crises, little blame is attributed to the organization; however, if an organization intentionally caused or actively contributed to the occurrence of an organizational crisis then stronger attributions of blame and responsibility are predicted.

Historically SCCT narrowly conceptualizes these attributions of responsibility to singular causal-based understandings (Weiner, 1996). In contrast to causal responsibility, which generally refers to the perceptions of the cause or origin of a problem/crisis (Fincham \& Jaspers, 1980; Shaver, 1985; Kruglanski, 1989), treatment responsibility is operationalized as whom or what has the ability or obligation to alleviate the effects of the problem/crisis (Brickman et al., 1982). The additional consideration of treatment responsibility suggests even when organizations are victims of crises a threat to the organization's reputation may occur or be amplified by stakeholders' perceptions of the organization's responsibility for alleviating the effects of the crisis. We argue that threats to an organization's reputation area function of both causal and treatment responsibility. Previous research expanded the SCCT conceptualization of crisis causality and found print-based news reports of crises emphasizing treatment responsibility amplified the reputational threats resulting from crises, in both victim and accident clusters, and also resulted in more negative effect in non-victim audiences (Mason, 2014, 2016). Drawing from extant literature we hypothesize:

H1) Compared to crisis news reports that do not include treatment responsibility statements, reports that include treatment responsibility statements will increase the degree of reputational threat, demonstrated by more negative perceptions of organizational reputations.

\section{User Comments}

Weber (2014) reports there is an increasing amount of user-generated content and this frequently supplements professionally generated online news content. User-generated content is defined as "content that is made available through publicly accessible transmission media such as the Internet; reflects some degree of creative effort; and is created for free, outside professional routines and practices," (Christodoulides et al., 2012, pg. 54-55). User-generated content facilitates the free-flow of opinion and sharing of experiences online (Wang \&Owyang, 2010). Thus, user comments provide a space for civic discourse and civic engagement toward timely and relevant news issues.

Online audiences are increasingly involved in the observation and interpretation of digital news content. Millner, Veil, and Sellnow (2011) label third party sources of critical information during crises as 'proxy communicators.' With access and opportunity members of digital audiences may perceive themselves to be digital influencers, or proxy communicators, advocating either on behalf of or against an organizations' interest during a time of crisis. "Although proxy communicators can fill the void created when an organization in crisis chooses to remain mute, this substitution is not without problems," (Ulmer, Sellnow, \& Seeger, 2014, pg. 157).

Houston, Hansen, and Nisbett (2011) argues that "because comments are a structural feature of online media content, they represent a computer-mediated version of interpersonal communication," (pg. 88) and allow for discussion and interaction among a variety of stakeholders. Previous investigations focusing on the persuasive impact of user comments in the consumer context found that negative user-generated product reviews decreased stakeholder's perceptions of an organization's trustworthiness (Pavlou \& Dimoka, 2006). User comments in response to blog posts have been found to polarize attitudes and influence risk perceptions toward particularly novel issues, such as emerging nanotechnology (Anderson et al., 2014). 
In news media, user comments have been found to impact the perceived quality of journalism (Prochazka, Weber,\& Schweiger, 2016); and also amplify prejudicial attitudes in online forums (Hsueh, Yogeeswaran, \& Malinen, 2015).User-generated content is a matter of concern to a wide-range of organizations, and many utilize reputation management software to scan and monitor for reputational threats emerging within digital environments (e.g., Radian6, Sysomos). If negative feedback is identified organizations have several response options. Some may simply choose to delete the comments if they control the platform on which they are expressed. If the platform is uncontrolled (e.g., online news websites) an organization may try to intervene by:(a) petitioning the distributor to remove and/or reposition the offending comments, (b) demanding a cease and desist, (c) requesting an internal or external review of the statements for accuracy, or (d) directly responding to the commentator.

\section{Theory of Emotional Stakeholders}

Understanding the persuasive impact of user comments to news reports of organizational crises is an important area of investigation yetit remains an underdeveloped area of inquiry within crisis communication literature. In this study we use the Theory of Emotional Stakeholders (TES) as a conceptual framework to experimentally test the persuasive impact of user comments on the attitudes and perceptions of organizational reputations and responsibility. Luoma-aho's (2006; 2009; 2010) Theory of Emotional Stakeholders (TES) conceives a faith-holder to be "a stakeholder who trusts the organization and has frequent personal experiences and contact with the organization," (2006, pg. 14), and a hateholder is defined as "stakeholders that feel strong distrust or even hate towards an organization" (2009, pg. 5). Although the theory is criticized for a lack of conceptual clarity concerning the definition of faith-holders and hateholders, as many individuals can feel extremely negative, without actually 'hating' an organization, we retain the terms in this study. In doing so we anticipate that faith-holders will express statements of support toward an organization in crisis, and hate-holders will be critical toward the organization. TES argues that hate-holders can damage the reputation of a company while, "faith-holders may hold the key to maintaining organizational legitimacy," (Luoma-aho, 2010, pg. 5). Given the variety of crisis types within the previously identified crisis clusters, and the wide array of comments that may result from exposure to the news story the below $R Q$ is offered.

$R Q 1)$ Compared to control, how will digital audiences evaluate organizational causal and treatment responsibility when digital news reports include user comments presented as (a) faith-holders, (b) hate-holders and a (c) corporate crisis response?

Recently emotion-focused crisis communication research has generated interest and attention from crisis communication scholars. A well-developed stream of research has previously examined the role of emotion in the selection of crisis response strategies and also attributions of crisis responsibility (Coombs \&Holladay, 2005; Coombs, Fediuk \& Holladay, 2007; Choi \&Lin, 2009; Kim \& Niederdeppe, 2013). Previous research has found that when stakeholders turn negative toward a company, they are more inclined to express their negative emotions on social media, such as on the company's Facebook page, corporate blog, and in response to news coverage (Choi \&Lin, 2009; Champoux et al.,2012; Einwiller \& Steilen, 2015; Pang et al.,2014;Haigh \& Wigley, 2015).

To date a significant portion of crisis communication scholarship has concentrated on negative emotional reactions of the stakeholders and effective corporate crisis responses to attenuate or augment negative reactions. Less is known about proxy support from an organization's faith-holders, who in crisis situations may voice support by offering positive evaluations of an organization's previous performance, or defending or protecting an organization's product, image, or brand. It remains unknown how user comments will influence the perceptions of audiences in response to online news reports of crisis events, therefore the below research questions are offered.

RQ2) Compared to control, will crisis clusters that include user comments from faith-holders (supportive) result in decreased reputational threats, demonstrated by less negative perceptions of organizational reputations?

RQ3) Compared to control, will crisis clusters that include user comments from hate-holders (critical) result in increased reputational threats, demonstrated by more negative perceptions of organizational reputations?

Faith-holders and hate-holders are not the only sources providing user comments to crisis reports, organizations may also formally engage by sharing or posting corporate crisis communication messages. Environmentally scanning in order to identify daily reputational threats online is rather easy, the choice whether or not to strategically and publicly engage is less clear. In general, user responses to news reports are outside the control of organizations; but as Byrd (2012) notes, organizations may choose to offer a strategic organizational response. It is unknown if and how organizational crisis responses within the user comments of crisis news reports will impact audience perceptions toward the organization's reputation therefore the below research question is offered.

$R Q 4)$ How will audiences assess an organization's reputation that engages online addressing a crisis in response to hate-holder user comments? 
Emotional responses to crisis situations are not uncommon. The association between exposure to online news reportsand emotional responses flows from cognitive appraisal theory. Cognitive appraisal argues that people do not experience emotions randomly but rather as a product of their own cognitive evaluations (appraisals) of an event or phenomenon (e.g., Ellsworth, 1991; Lazarus, 1991; Ortony, Clore, \& Collins, 1988; Roseman, 1991).Within crisis communication literature emotion has been studied in a variety of ways including: towards specific crisis events (Fredrickson, Tugade, Waugh, \& Larking, 2003; Utz, Schultz, \& Glocka, 2013), coping strategies in response to crisis events (Jin, 2009; 2010) and assessing the utility and effectiveness of specific crisis response messages (Jin, Pang,\& Cameron, 2010a; 2010b; Kim \& Cameron, 2011; Claeys, Cauberghe, \& Leysen, 2013).These studies reveal that positive emotion (i.e., optimism, contentness, and happiness) helps individuals adapt and cope to crisis-induced stress, and therefore contributes to resiliency. Negative emotions (i.e., anger, sadness) have been reported to be closely associated with the perceived predictability or organizational control of crisis events, and may impact the perceptions of an organization's reputation and responsibility, in addition to stakeholders' subsequent acceptance of crisis response messages. In the SCCT theoretical frame higher levels of anger are associated with the intentional/preventable crisis cluster compared tocrises emerging within the victim cluster, as the acts are perceived to be avoidable. This study measures the emotional reactions to user comments of online crisis news reports and hypothesizes the following:

H2) Compared to control, crisis reports that are followed by user comments from hate-holders will generate elevated levels of negative effect in the accidental and victim crisis clusters.

The next section of the manuscript reports the process and procedures used to develop the experimental materials, recruit participants, and data gathering strategies used to answer the hypotheses and research questions posed.

\section{Method}

Respondents in this study included 230 participants recruited into an online message processing study hosted through the Communication Research Lab (CRL) at a Midwestern university. All materials and measures received approval from the Institutional Review Board (IRB). Responses were gathered using Qualtrics®online data collection software and migrated into IBM Statistical Package for the Social Sciences 22 (SPSS) for analysis.

\section{Sample Description}

Participants were $27.8 \%$ male and $64.3 \%$ female; with an average age of 24.2 yrs. of age; $78.7 \%$ were Caucasian, $7 \%$ Asian, 5.2\% African American, 5.2\% Hispanic, and 4.3\% Native American. Education levels varied with 58\% completing a high school/GED, 10.7\% held an Associate's degree, 19.1\% a Bachelors, $5.1 \%$ held a Master's degree, and $4.7 \%$ a Ph.D., MFA, M.D. or other terminal degree.

Participants first provided demographic data and were then informed that they would be shown a digital news report. They were instructed to read the news report thoroughly, including any comments in the feedback section. After reading the news report participants responded to the dependent measures. Each participant read two news articles. The crisis reports were randomized so that no participant received a news report from the same crisis cluster.

\section{Message Development}

A total of 48 digital crisis news reports were produced. As in previous studies, crisis situations were adapted from actual cases, with limited geographic connection to the sample population; therefore, the researchers hold that participants would have limited a priori knowledge of the scenarios. Two crisis types from within the victim, accidental and preventative crisis clusters were included in the study. The victim scenarios consisted of a natural disaster (e.g., CA drought) and a product tampering case (e.g., Enfamil baby formula). The accidental scenarios were represented by a technical-issue (e.g., chemical leak) and a product recall (e.g., Whirlpool coffee makers).The intentional cluster included a fraudulent marketing case (e.g., Purdue-OxyContin) and a financial fraud case (e.g., Bank of America mortgage fraud).We controlled for several message features including: message source, comment length, user name, and frequency of comments. User comments were manipulated and appeared below the digital news reports. Four conditions for each message were created and include: supportive (faith-holders), critical (hate-holders), organizational, and control (no user comments).Statements from faith-holders included statements of positive experiences and testimonies while hate-holders user comments included statements of critique, blame, and disappointment. For example, the Bank of America (BOA) scenario, representing an intentional/preventable crisis type, included user comments from faith-holders such as: "Banked with them for years, never had a problem" or "Bank of America is awesome they support schools, local communities, and small families." The user-comments of hate-holders were represented by statements such as "BOA=bank of fraud" and "I would have gone to prison for this but they get fines and a slap on the wrist."All visual representations of the user comments were held consistent so that the number of comments and user identities did not change. 
No mug shots or photos were used to represent the user comments, only an alphabetical or numerical character (i.e., "A" or " $2 ")$. A description of each crisis is provided in Table 1 of this manuscript, an example of the experimental reports is included in the appendix.

\section{Dependent Variables}

Organization Reputation. An abbreviated organizational reputation scale was used. The 7-pt,4-item scale included statements such as, after reading the report (a) I feel more negative towards the organization, (b) I trust the organization more, (c) I feel more positive toward the organization, and (d) I do not trust the organization as much. Each item was assessed on a 7-pt scale ranging from 1 (strongly disagree) to 7 (strongly agree).Reliability for all criterions in the current study was assessed using Cronbach's alpha $(\alpha=.89, M=4.55, S D=.53)$.

Causal Responsibility. The 3-item causal responsibility measurement derived from Brickman et al. (1982). The statements used in the present study were: (a) to what extent do you believe the organization is responsible for the cause of this situation,(b) to what extent do you believe the organization could have avoided the problems they now experience, and (c) to what extent do you believe the organization could have controlled the current situation? Each item was assessed on a 7-pt scale ranging from 1 (not at all) to 7 (very much). Scale reliability was again assessed using Cronbach's alpha $(\alpha=.87, M=4.55, S D=.12)$.

Treatment Responsibility. Similar to the above treatment responsibility (TR) was assessed on a 7-pt, 3-item scale (Brickman et al., 1982). Scale items included statements such as: (a) to what extent do you believe the organization is responsible for solving this issue;(b) to what extent do you believe the organization can provide solutions for this problem;(c) to what extent do you believe the organization is capable of responding to this issue? $(\alpha=.84, M=5.09$, $S D=.65)$.

Affect. An adapted version of Dillard and Peck's (2001) affective response scale was used to measure the dimensions of anger, fear, contentment, and happiness. The 7-pt, 10-item scale consisting of bi-polar opposites such asangryhappy, annoyed-pleased, aggravated-relieved, scared, happy-sad. Reliability was established at $(\alpha=.92, M=3.28$, $S D=.50)$.

\begin{tabular}{|c|c|c|c|c|c|c|}
\hline & Crisis & Description & TR & Faith-holders & Hate-holders & Org. Response \\
\hline \multirow{2}{*}{ 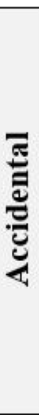 } & $\begin{array}{l}\text { Technical-error } \\
\text {-accident }\end{array}$ & $\begin{array}{l}\text { A Gen Chem } \\
\text { chemical leak } \\
\text { due to car } \\
\text { accident in } \\
\text { VA }\end{array}$ & $\begin{array}{l}\text { Refusal to test safe } \\
\text { guards at other plants }\end{array}$ & $\begin{array}{l}\text { That plant kept food } \\
\text { on the table for my } \\
\text { family for } 2 \\
\text { generations; My } \\
\text { cousin works at that } \\
\text { plant- thankfully no } \\
\text { one was hurt. }\end{array}$ & $\begin{array}{l}\text { The company } \\
\text { shouldn't produce } \\
\text { what they can't } \\
\text { protect; How much } \\
\text { sulfer acid mist was } \\
\text { released into the air } \\
\text { this time. }\end{array}$ & $\begin{array}{l}\text { We do not anticipate additional chemical leaks because of future rolling } \\
\text { blackouts. We share the energy grid with hospitals and other essential services } \\
\text { and are exempt from forced blackouts. We are actively working to contain the } \\
\text { leak and protect those impacted. We will provide a detailed report to the general } \\
\text { public on the cause and consequences of this event in order to avoid future leaks } \\
\text { when more information is available. To our knowledge the driver of the truck is } \\
\mathrm{OK} \text {, we are dedicating all available resources to protect everyone from chemical } \\
\text { exposure. If you have questions or concerns please contact us at } \\
\text { mediagenchem.com }\end{array}$ \\
\hline & $\begin{array}{l}\text { Technical- } \\
\text { error-product } \\
\text { harm }\end{array}$ & $\begin{array}{l}\text { Whirlpool } \\
\text { recall on } \\
\text { coffee makers }\end{array}$ & $\begin{array}{l}\text { Customers } \\
\text { responsible for } \\
\text { paying for returns } \\
\text { and replacements }\end{array}$ & $\begin{array}{l}\text { I've used Whirlpool } \\
\text { products since I was } \\
\text { little- never had a } \\
\text { problem.; Love my } \\
\text { Whirlpool fridge! }\end{array}$ & $\begin{array}{l}\text { We need to pay for } \\
\text { your mistakes-no } \\
\text { thanks!; Welcome to } \\
\text { America where } \\
\text { everything costs so } \\
\text { much but is cheaply } \\
\text { made in China. }\end{array}$ & $\begin{array}{l}\text { Our products are fully-tested before we introduce them into the consumer } \\
\text { market. We are making our customers aware of an issue that was brought to our } \\
\text { attention by the manufacturer of the electrical circuit used in the impacted } \\
\text { models. We regret this inconvenience and look forward to working with our } \\
\text { customers to repair or replace the impacted models. media@whirlpool.com }\end{array}$ \\
\hline \multirow{2}{*}{ 罗 } & $\begin{array}{l}\text { Product } \\
\text { tampering }\end{array}$ & $\begin{array}{c}\text { Product } \\
\text { tampering at } \\
\text { local retailers }\end{array}$ & $\begin{array}{l}\text { Retailer did not } \\
\text { remove all cans from } \\
\text { shelves }\end{array}$ & $\begin{array}{l}\text { This is so sad! What } \\
\text { sicko would target } \\
\text { babies?; I hope this } \\
\text { doesn't ruin Enfamil- } \\
\text { I raised } 3 \text { kids on that } \\
\text { stuff! }\end{array}$ & $\begin{array}{l}\text { I doubt they can } \\
\text { resolve this- there are } \\
\text { too many people } \\
\text { involved in the process } \\
\text { of making formula; I } \\
\text { no longer trust baby } \\
\text { formula- back to the } \\
\text { ol' natural way }\end{array}$ & $\begin{array}{l}\text { We are actively investigating this matter. For the time being all of our products } \\
\text { are being pulled from retailers' shelves. If you have any information or } \\
\text { questions about these events contact us at media'aenfamil.com }\end{array}$ \\
\hline & $\begin{array}{l}\text { Natural } \\
\text { Disaster }\end{array}$ & $\begin{array}{l}\text { CA-natural } \\
\text { disaster } \\
\text { resulting from } \\
\text { drought }\end{array}$ & $\begin{array}{l}\text { Disaster funds only } \\
\text { available to farmers } \\
\text { not other } \\
\text { stakeholders (i.e., } \\
\text { transportation and } \\
\text { manufacturing } \\
\text { workers). }\end{array}$ & $\begin{array}{l}\text { Good for CA- } \\
\text { helping the people; } \\
\text { Farmers could use as } \\
\text { much help as they } \\
\text { can get }\end{array}$ & $\begin{array}{l}\text { Farmers get benefits } \\
\text { but no one else- the } \\
\text { foods got to move!; } \\
\text { Glad to know we all } \\
\text { have to suffer. }\end{array}$ & $\begin{array}{l}\text { This drought has negatively impacted California more than any other state in the } \\
\text { nation. The new disaster declaration at the federal level has allowed us to offer } \\
\text { some relief to our local farmers. Unfortunately the federal funds are restricted to } \\
\text { these individuals and organizations. We are actively seeking resources to assist } \\
\text { others impacted by this disaster. If you have any questions feel free to contact } \\
\text { me at johanns@ @nc.gov }\end{array}$ \\
\hline \multirow{2}{*}{ 㿣 } & $\begin{array}{l}\text { Organizational } \\
\text { misdeed/misco } \\
\text { nduct }\end{array}$ & $\begin{array}{c}\text { Bank of } \\
\text { America } \\
\text { Mortgage } \\
\text { Crisis }\end{array}$ & $\begin{array}{l}\text { Bank of America has } \\
\text { not provided any } \\
\text { compensation/payme } \\
\text { nts }\end{array}$ & $\begin{array}{l}\text { Banked with them for } \\
\text { years- never has a } \\
\text { problem; BOA is } \\
\text { awesome- they } \\
\text { support schools, local } \\
\text { communities, and } \\
\text { small families. }\end{array}$ & $\begin{array}{l}\text { Bank of America= } \\
\text { Bank of fraud; I would } \\
\text { have gone to prison for } \\
\text { this but they get some } \\
\text { fines and a slap on the } \\
\text { wrist! }\end{array}$ & $\begin{array}{l}\text { Bank of America regrets these events. Bank of America looks forward to } \\
\text { closing the doors on this case and moving forward in order to continue to } \\
\text { provide our banking services to individuals and small businesses throughout the } \\
\text { U.S. The fines and penalties resulting from this case will impact Bank of } \\
\text { America for many years to come. If you have any questions or concerns please } \\
\text { contact us at media@boa.org. }\end{array}$ \\
\hline & $\begin{array}{l}\text { Organizational } \\
\text { misdeed -with } \\
\text { injuries }\end{array}$ & $\begin{array}{l}\text { Purdue- } \\
\text { OxyContin } \\
\text { Marketing }\end{array}$ & $\begin{array}{l}\text { Purdue has not } \\
\text { implemented } \\
\text { training, monitoring } \\
\text { or compliance }\end{array}$ & $\begin{array}{l}\text { Purdue Pharma is } \\
\text { more than this one } \\
\text { mistake; My uncle } \\
\text { used the drug...it } \\
\text { saved him from a lot } \\
\text { of pain. }\end{array}$ & $\begin{array}{l}1 / 2 \text { a YEARS } \$ \$ \$ ! \\
\text { Should have doubled } \\
\text { the fine; They } \\
\text { knowing killed....and } \\
\text { addicted people }\end{array}$ & $\begin{array}{l}\text { Purdue will appeal this decision. Our focus has and will remain on producing } \\
\text { medications that help people live full and long lives. Purdue apologizes for the } \\
\text { circumstances surrounding these events. Although we can't control when our } \\
\text { products are misused we are dedicated to manufacturing safe, affordable } \\
\text { medication. If you have questions or concerns contact me media@purdue.org }\end{array}$ \\
\hline
\end{tabular}




\section{Report of Findings}

Prior to reporting the omnibus and univariate results for the research questions and hypotheses advanced a test of discriminant validity was conducted to ensure that attributions of causal and treatment responsibility are in fact discreet constructs. An exploratory factor analysis using principal component method used an orthogonal Varimax rotation with Kaiser Normalization. The results of the principle component factor analysis revealed a two-factor solution (each with eigenvalues $>1$ ) with items configuring as predicted and accounting for $83 \%$ of the variance.

$H 1$ held that crisis reports including treatment responsibility statements will pose a greater degree of reputational threat demonstrated by lower evaluations of organizational reputations compared to reports that only include causal responsibility statements. An ANOVA was computed with treatment responsibility as the fixed factor and organizational reputation as the dependent variable. Significant differences were found $F(3,349)=13.38, p<.001$, $\eta^{2}=.10$. Compared to control, or those reports which did not include treatment responsibility statements, $(M=4.89$, $S D=1.15$ ), events in the accidental cluster that included the treatment responsibility statements reported the most negative perception of organizational reputations $(M=5.28, S D=.96)$ as did the crises in the intentional cluster $(M=4.96, S D=.91)$.

In order to answer $R Q 1$ a multivariate analysis of variance (MANOVA) was computed with crisis cluster and user comments as the predictor variables and organizational responsibility as the dependent variable. The MANOVA results indicated significant differences on the factors of user comments $F(3,335)=6.02, p<.001, \eta^{2}=.05$ and crisis cluster $F(2,335)=23.91, p<.001, \eta^{2}=.13$. The univariate tests reported in Table 2 show that irrespective of participants being exposed to user comments from faith-holders, hate-holders, or the organization at the center of the crisis in the accidental or victim clusters they were more likely to report increased treatment responsibility, compared to control. Those who were not exposed to any user comments still reported higher treatment responsibility, opposed to causal responsibility in the accidental $(M=5.15, S D=1.47)$ and victim clusters $(M=4.38, S D=1.64)$.

Table 2.Perceptions of Organizational Responsibility resulting from User Comments Intentional Crises

$\begin{array}{lllllll} & \text { Cause } & \text { Treatment } & \text { Cause } & \text { Treatment } & \text { Cause } & \text { Treatment } \\ \text { Faith-holders } & 5.03(1.37) & 5.20(1.28)^{\mathrm{a}} & 5.28(.86)^{\mathrm{a}} & 5.62(1.13) & 3.03(1.68)^{\mathrm{a}} & 5.54(1.17) \\ \text { Hate-holders } & 4.86(1.29)^{\mathrm{a}} & 4.60(1.20) & 5.16(1.11) & 5.48(1.15) & 3.47(1.77) & 4.89(1.41) \\ \text { Org. } \text { Response } & 5.48(.87) & 4.44(1.24) & 5.26(1.16) & 5.75(1.19) & 3.68(1.18) & 4.93(1.24) \\ \text { Control } & 5.65(1.02) & 4.88(1.52) & 5.07(1.04) & 5.15(1.47)^{\mathrm{a}} & 2.64(1.48) & 4.38(1.64)^{\mathrm{a}}\end{array}$

Note: ${ }^{\mathrm{a}}$ indicates significant at $\mathrm{p}<.001$, a 7 -pt Likert scale ranging from not at all to very much, higher scores indicate greater organizational responsibility.

The results show that subjects exposed to faith-holder statements reported less causal responsibility attributions $(M=5.28, S D=.86)$ and more treatment responsibility $(M=5.62, S D=1.13)$ in the accidental crisis cluster. Similar findings are noted in the victim crisis cluster for causal $(M=3.03, S D=1.68)$ and treatment responsibility $(M=5.54$, $S D=1.17)$. Findings show that compared to control, critical comments from hate-holders within the victim cluster increased perceived causal $(M=3.47, S D=1.77)$ and treatment responsibility $(M=4.89, S D=1.14)$. User comments from hate-holders impacted perceptions toward causal $(M=5.16, S D=1.11)$ and treatment responsibility $(M=5.48, S D=1.15)$ within the accidental crisis cluster. Compared to the accidental and preventable crisis clusters, participants who were exposed to crisis news reports when organizations are the victims of crisis events reported, as would be expected, the lowest amount of causal responsibility $(M=2.64, S D=1.48)$ and treatment responsibility $(M=4.38$, $S D=1.64)$.Interestingly, when organizations acted inappropriately within the intentional/prevention crisis cluster, and respondents were exposed to news reports including comments from hate-holders, they reported the lowest amount of causal $(M=4.86, S D=4.60)$ and treatment responsibility $(M=4.60, S D=1.20)$.

$R Q s 2$ and 3 sought to understand if user comments from faith-holders and hate-holders would augment public perception of organizational responsibility relative to the control condition, no user comments. In order to answer $R Q 2$ and $R Q 3$ an analysis of variance (ANOVA) was computed with user comment type (e.g., supportive, critical) as the predictor variable and organizational reputation as the dependent variable. The ANOVA revealed significant differences $F(2,146)=2.92, p=.05, \eta^{2}=.04$. Findings show that compared to both control $(M=4.77, S D=.79)$ and hateholders $(M=4.89, S D=.71)$, digital news reports including faith-holders statements in the user comments resulted in more negative evaluations of organizational reputations $(M=5.15, S D=.71)$. RQ4sought to understand audience responses to corporate crisis response messages via user comments. 
An ANOVA was computed and found that compared to the control condition, which had no user comments, participants exposed to crisis reports with user comments from the impacted organization reported greater organizational responsibility in the accidental cluster toward both cause $(M=5.26, S D=1.19)$ and treatment responsibility $(M=5.75, S D=1.19)$ and the victim cluster toward causal $(M=3.68, S D=1.18)$ and treatment responsibility $(M=4.93, S D=1.24)$. In contrast, when organizations offered a corporate crisis communication statement participants exposed to crisis reports in the intentional cluster reported less causal $(M=5.48, S D=.87)$ and treatment responsibility $(M=4.44, S D=1.47)$. The strongest perceived causal responsibility came in response to user comments including an organizational response $(M=5.48, S D=.87)$, while the strongest reported perceived treatment responsibility came in reaction to news reports featuring user comments from faith-holders $(M=5.54, S D=1.17)$.

Finally, $H 2$ posited that compared to the control condition, crisis reports that were followed by user comments from hate-holders would generate elevated levels of negative effect in the victim and accidental crisis clusters. A univariate analysis of variance was computed with user comment and crisis cluster as the independent variables and affect as the dependent variable. Results indicated there were no significant interactions $F(6,352)=.44, p>.05$, or within the factors of user comments $F(3,352)=1.81, p>.05$ and crisis cluster $F(2,352)=2.18, p>.05$.

\begin{tabular}{lccc} 
& \multicolumn{3}{c}{ Table 3.Impact of User Comments on Negative Affect } \\
Faith-holders & Intentional & Accidental & Victim \\
Hate-holders & $3.40(.97)$ & $3.57(.96)$ & $3.38(1.59)$ \\
Org. Response & $3.14(1.02)$ & $3.20(.84)$ & $3.29(.81)$ \\
Control & $2.89(.77)$ & $3.39(.61)$ & $3.13(.75)$ \\
& $3.13(.80)$ & $3.46(.96)$ & $3.28(.84)$
\end{tabular}

Note: a 7-pt Likert scale was used to measure affect; lower numbers indicate increased negative affect.

The following section of the manuscript will discuss these findings in more detail. Methodological limitations and future directions for additional study are provided.

\section{Discussion, Limitations, and Future Directions}

This investigation sought to more fully understand how user responses from faith-holders, hate-holders, and organizations impact audience perceptions of organizational reputation and responsibility in digital news reports about organizational crisis events. Several findings emerged that offer important theoretical and pragmatic consideration for crisis communication practitioners. To begin, we found that no matter what type of user comment, whether it be from faith-holders, hate-holders, or the organization involved in the crisis; participants were more likely to report increased treatment responsibility specifically in the accidental and victim clusters. This is germane to general beliefs such as: "It's not your fault-- you might not have caused it but you are responsible for fixing it," or "It may be an accident but you still need to pick/clean it up."We argue both causal and treatment should be factored with anticipating the degree of reputational threat posed by organizational crises. It maybe that crises occurring within specific clusters sensitizes audiences such that they do not change their evaluations of cause, but rather increase their attributions of treatment responsibility.

These findings also reveal that in cases where organizations have clearly acted inappropriately (e.g., intentional/prevention crisis cluster),participants exposed to crisis reports including user comments from hate-holders reported the lowest amount of causal responsibility $(M=4.86, S D=4.60)$ and a corporate crisis communication message from the impacted organization resulted in less treatment responsibility $(M=4.44, S D=1.24)$. This is an unexpected and perplexing finding. It may be that in these crisis states, when fault and accountability are clear, rather than fostering additional scrutiny or negative perceptions based on the hate-holders comments, a sense of organizational empathy emerges which attenuates the strong negative reputational threats anticipated to result from these events. These findings may also result from the specific organizations used to represent the intentional/preventative crisis cluster (i.e., a bank and pharmaceutical company). The hedonic relevance (i.e., personal health and personal finances) of these organizations may alter individuals' attitude toward organizational responsibility (for review see Miller, 2016).Further testing of a more robust variety of crises representing these clusters is needed.

Our study found that user comments from faith-holders reduced causal responsibility in the intentional cluster $(M=5.03, S D=1.37)$ compared to the control condition; however, when organizations were facing preventable crises, user comments from faith-holders increased treatment responsibility $(M=5.20, S D=1.28)$. This can be explained as psychological reactance to faith-holders' support for organizations facing crises, specifically in the intentional/preventative cluster. If an organization, either with intent or through neglect, caused a crisis, others may respond negatively to the faith-holders' defense of the organization. This is an important finding that may aid future decision-making related to encouraging or requesting support from faith-holders in certain types of crises situations. 
If faith-holders are activated in intentional/preventable crisis statesit may create a boomerang effect that actually increases perceptions of treatment responsibility and further erodes organizational support. There was no established factorial model for investigating this topic and retrospectively there are some weaknesses in both the design and operationalization of the constructs. To begin, this study was an initial first attempt to experimentally test the Theory of Emotional Stakeholders (TES) concepts of 'faith-holders' and 'hate-holders' represented through user comments in response to online news reports of crisis situations. There are some considerations related to the selection of the news source of the crisis reports and the limitations of the organizational crisis response manipulations within the experimental materials. We offer the below recommendations for scholars seeking to advance this line of inquiry in the future.

The research foci of online user comments are not without controversy. Suler (2004) argues there is an 'online disinhibition effect' at-play which predicts that when an individual's identity is unknown, there is little accountability for their actions or words, thus their inhibition drops. Through this digital veil of anonymity some individuals may engage in uncivil, antagonistic and/or hate-filled speech more freely and without fear of the consequence. Because negative user comments have been found to decrease the perceived quality of journalism (Lee \& Jang, 2010) many news organizations are now disabling the option of posting user comments, noting that negative user comments devalue the perceived quality of news journalism in the eyes of others (e.g., NPR, Bloomberg, \& Popular Science). Opposed to banning user comments completely, some news organizations have begun requiring registration prior to posting, or requiring log-in via personal social media (e.g. Facebook, Twitter) thereby removing concerns of anonymity. Santana (2014) reported that $48.9 \%$ of the 137 largest U.S. newspapers have disallowed anonymity in their commenting forums, $41.6 \%$ allow anonymity and $9.4 \%$ do not offer comment forums (Santana, 2014). It is unclear how future user comment policy changes will impact the influential nature of these communication forumsto online news reports of crisis situations in the long-term, however the subject will likely attract attention from scholars, applied communication practitioners and organizational leaders interested in engaging in online reputation management for the foreseeable future.

At the time the experimental materials employed in this study were developed the goal was tocreate a generalized,3-6 line organizational crisis response that acknowledged the crisis and provided a feedback loop to the organization (i.e., phone number, email, website, etc.). Because of this approach there is no clear theoretical classification of the organizational crisis communication response strategies utilized in this study. Some responses maybe considered transcendent strategies, while others included explicit statements of regret. In order to better understand which type of crisis response best addresses the variety of faith-holder and hate-holder user comments, additional research, replication and refinement are needed. Future work may employ a broader range of accommodative and non-accommodative organizational crisis communication strategies. Although these concerns were outside the scope of the present investigation, they certainly warrant future study.

The Theory of Emotional Stakeholders (TES) conceptualizes three broad stakeholder categories: faith-holders, hateholders, and fake-holders. No responses from "fake-holders" were incorporated into this study as these individuals are generally characterized as using false or fake personas to alter or change public perception. This study narrowly aimed to more clearly understand the impact of supportive, critical, and corporate user comments, thus fake holders were omitted from the analysis. Additional study of the persuasive impact of fake-holders is needed. Whether the motivation is to engage for purposes of deception, instigation, or agitation these individuals may adopt pseudo-personas or use sock-puppetry to augment positive and/or negative emotions of others in online social environments. Future work should consider high and low organizational involvement by stakeholders. Highly involved stakeholders may report more engagement, demonstrated by increased information seeking and sharing, and also create more online user comments. Experimentally testing and measuring these effects will remain a challenge. Alternative methods such as eye-tracking- and log-file-analysis may be useful methodologies to further understand the persuasive impact of the communication exchanges in these forums.

User comments are not the only variable influencing the perceptions of organizations presented in digital news reports of crisis events. Baden and Springer (2014) maintain that "reactions to news coverage, user commentary is inevitably influenced by the information and frames provided therein," (pg. 532) thus additional work exploring the media framing of crises is encouraged. In this study no general attitudes, a priori knowledge, or involvement levels with the organizations were measured prior to the presentation of experimental materials. Pang (2013) contends that if "an accusation that was circulated online resonated with pre-existing negative experiences with the organization/individual experienced by other stakeholders or if it reinforced a pre-existing negative view held by the organization, it [is] more likely to be shared and escalated," (pg. 104). 
Further investigations using pre- post designs may provide a better contrast while measuring additional variables such as participants' knowledge about or engagement with the organization at the center of the crisis (i.e., organizational involvement) and perceptions of the reporting journalism/reporting agency/network (i.e., source credibility). In doing so offer more insight can be gleaned into attitudinal and perceptual change.

Ongoing experimental and laboratory studies along with case studies will continue to inform the strategic choices organizations make when deciding whether or not to engage stakeholders online in response to user comments. Luomaaho(2010) argues that hate-holders can damage the reputation of a company, while "faith-holders may hold the key to maintaining organizational legitimacy," (pg. 5). Our findings indicate the relationship between organizations and faithholders may only be mutually beneficial in certain crisis-types and within specificcrisis clusters. This study found that (1) hate-holders may lower assessments of organizational blame in the intentional cluster, perhaps demonstrating an empathetic response, while (2) faith-holders may undermine an organization's reputation when defending crises emerging from within the intentional/preventable cluster. Clearly further investigation and replication of findings is needed. Scholarship of this nature will help to inform the optimal selection and delivery of strategic crisis messages needed to effectively manage the emotional response of stakeholders during times of organizational crisis.

TES provides new avenues for additional subjects of scholarly inquiry outside of crisis communication and reputational management. Organizations frequently engage in issues management and are expected to take formal positions on controversial issues (i.e., restroom access/use, equality of pay, data privacy and management, etc.). Using TES for analyzing stakeholder responses to organizational position statements (e.g., white papers) may help to more fully understand the emotions of both internal and external stakeholder groups.

\section{Conclusion}

Negative user-generated content may erode positive stakeholder relationships and damage organizational reputations. Our findings reveal that user comments from organizations, faith-holders, and hate-holdersall contribute to audience evaluations of organizational responsibility, both causal and treatment, and impact organizational reputations. Because crisis events can prompt information-seeking and sharing behaviors, understanding if and how to strategically respond is an important consideration for practitioners who are expected to skillfully engage in online relation building and reputation management.

Acknowledgements: William Eigenmann, Jeanine Kunshek, Caitlen Almond, Shonté Clay, Taylor Piva, Li Sih-Yuan, Carole Liston, Jo Byrnes, and Jennifer Hellwig were graduate students in the Department of Communication and served as research assistants in this experimental study. We thank our colleagues and participants who volunteered to participate in this experimental study.

\section{References}

Anderson, A. A., Brossard, D., Scheufele, D. A., Xenos, M. A., \&Ladwig, P. (2014). The "nasty effect": Online incivility and risk perceptions of emerging technologies. Journal of Computer-Mediated Communication, 19(3), 373-387. http://doi.org/10.1111/jcc4.12009

Baden, C., \& Springer, N. (2014). Com(ple)menting the news on the financial crisis: The contribution of news users' commentary to the diversity of viewpoints in the public debate. European Journal of Communication, 29(5), 529-548.

Brickman, P., Rabinowitz, V.C., Coates, D., Cohn, E., \& Kidder, L. (1982). Models of helpingand Coping.American Psycholoist, 37, 364-384.

Byrd, S. (2012). Hi fans! Tell us your story! Incorporating a stewardship-based social media strategy to maintain brand reputation during a crisis,CorporateCommunications: An International Journal, 17(3), 241-254.

Carpenter, S. (2010). A study of content diversity in online citizen journalism and online newspaper articles. New Media \& Society, 12(7), 1064-1084. doi:10.1177/1461444809348772

Champoux, V., Durgee, J., and McGlynn, L. (2012), Corporate Facebook pages:when "fans" attack.Journal of Business Strategy, 33(2), 22-30.

Choi, Y., \& Lin, Y. (2009). Consumer responses to Mattel product recalls posted on online bulletin boards: Exploring two types of emotion. Journal of Public Relations Research, 21(2), 198-207. doi:10.1080/10627260802557506

Christodoulides, G., Jevons, C., \&Bonhomme, J. (2012). Memo to marketers: Quantitative evidence for change: How user-generated content really affects brands. Journal of Advertising Research, 52(1), 53-64. doi:10.2501/JAR52-1-053-064

Claeys, A., Cauberghe, V., \&Leysen, J. (2013). Implications of stealing thunder for the impact of expressing emotions in organizational crisis communication. Journal of Applied Communication Research, 41(3), 293. doi:10.1080/00909882.2013.806991 
Coombs, W.T. (2004). Impact of past crises on current crisis communications: Insights from situational crisis communication theory, Journal of Business Communication, 41, 265-289.

Coombs, W.T. (2007). Crisis management and communications, Institute for Public Relations. Retrieved from http://www.instituteforpr.orgaccessed online publication 20 Sept 2009.

Coombs, W.T. \& Holladay, S.J. (1996). Communication and attributions in a crisis: An experimental study of crisis communication. Journal of Public Relations Research, 8(4),279-295.

Coombs, W.T. \& Holladay, S.J. (2002). Helping crisis managers protect reputational assets: Initial tests of the situational crisis communication theory, Management Communication Quarterly, 16, 165-186.

Coombs, W.T. \& Holladay, S.J. (2006). Halo or reputational capital:Reputation and crisis management. Journal of Communication Management, 10(2), 123-137.

Coombs, W.T., Fediuk, T., \&Holladay, S.J. (2007), Further explorations ofpost-crisis communication and stakeholder anger: The negative communication dynamic model. Paper presented at the 10th International Public Relations Conference, Miami, FL,USA.

Coombs, W.T., \& Holladay, S.J. (2005). An Exploratory Study of Stakeholder Emotions:Affect and Crises. In Neal M. Ashkanasy, Wilfred J. Zerbe, Charmine E.J. Härtel (Eds.) The Effect of Affect in Organizational Settings (Research on Emotion in Organizations, Volume 1) Emerald Group Publishing Limited,263-280.

Dillard, J. P., \& Peck, E. (2001). Persuasion and the structure of affect: Dual systems and discrete emotions as complementary models. Human Communication Research, 27, 38-68.

Domingo, D., Quandt, .T, Heinonen, A, Paulussen, S., Singer, J., \&Vujnovic, M. (2008). Participatory journalism practices in the media and beyond: An international comparative study of initiatives in online newspapers. Journalism Practice, 2(3), 326-342.

Einwiller, S.A. \&Steilen, S. (2015). Handling complaints on social network sites - An analysis of complaints and complaint responses on Facebook and Twitter pages of large US companies. Public Relations Review 41(2), (Jun 2015): 195.

Ellsworth, P.C. (1991). Some implications of cognitive appraisal theories of emotion. InK.Strongman (Ed.), International review of studies on emotion, 143-161, New York: Wiley.

Fincham, F.D. \& Jaspers, J.M. (1980). Attribution of responsibility: From man the scientist to man as lawyer. In Berkowitz L. (Ed.), Advances in experimental social psychology(Vol. 13). New York: Academic Press.

Fredrickson, B. L., Tugade, M. M., Waugh, C. E., \& Larkin, G. R. (2003). What good are positive emotions in crises? A prospective study of resilience and emotions following the terrorist attacks on the united states on September 11th, 2001. Journal of Personality and Social Psychology, 84(2), 365-376. doi:10.1037/0022-3514.84.2.365

Haigh, M. M., \&Wigley, S. (2015). Examining the impact of negative, user-generated content on stakeholders. Corporate Communications: An International Journal, 20(1), 63-75. doi:10.1108/CCIJ-02-2013-0010

Hart, L. (2011). Social media. In J. Doorley\&H.F. Garcia (Eds.), Reputation Management: The Key to Successful Public Relations and Corporate Communication, 2nd ed., Routledge, New York, NY, pp. 112 - 133.

Herminda, A. (2011). Mechanisms of participation: How audience options shape the conversations. In Singer J.B., Herminda, A., Domingo, D. and et al. (Eds). Participatory Journalism: Guarding Open Gates at Online Newspapers. Chichester, UK: Wiley.

Houston, J. B., Hansen, G. J., \&Nisbett, G. S. (2011). Influence of user comments on perceptions of media bias and third-person effect in online news. Electronic News, 5(2), 79-92.doi:10.1177/1931243111407618

Hsueh, M., Yogeeswaran, K., \&Malinen, S. (2015). Leave your comment below: Can biased online comments influence our own prejudicial attitudes and behaviors? Human Communication Research, 41(4), 557-576. http://doi.org/10.1111/hcre.12059

Jenkins, H. (2006). Convergence culture: Where old and new media collide. New York: University Press.

Jin, Y. (2009). The effects of public's cognitive appraisal of emotions in crises on crisis coping and strategy assessment. Public Relations Review, 35(3), 310-313. doi:10.1016/j.pubrev.2009.02.003

Jin, Y. (2010). Making sense sensibly in crisis communication: How publics' crisis appraisals influence their negative emotions, coping strategy preferences, and crisis response acceptance. Communication Research, 37(4), 522552. doi:10.1177/0093650210368256

Jin, Y., Pang, A., \& Cameron, G. T. (2010a). The role of emotions in crisis responses. Corporate Communications: An International Journal, 15(4), 428-452. doi:10.1108/13563281011085529

Jin, Y., Pang, A., \& Cameron, G. T. (2010b). The role of emotions in crisis responses: Inaugural test of the integrated crisis mapping (ICM) model. Corporate Communications, 15(4), 428-452. doi:10.1108/13563281011085529

Kim, Y. (2001). Measuring the bottom-line impact of corporate public relations. Journalism and Mass Communication Quarterly, 77(2), 273-291. 
Kim, H. J., \& Cameron, G. T. (2011). Emotions matter in crisis: The role of anger and sadness in the publics' response to crisis news framing and corporate crisis response. Communication Research, 38(6), 826-855. doi:10.1177/0093650210385813

Kim, H. J.\&Niederdeppe, K. (2013). The role of emotional response during an H1N1influenzapandemic on a college campus.Journal of Public Relations Research, 25, 30-50.

Kruglanski, A.W. (1989). Lay epistemics and human knowledge: Cognitive and motivational bases, New York: Plenum.

Lazarus, R.S., (1991). Emotion and adaptation. New York: Oxford University Press. In Pervin,A. (Ed.).Handbook of personality: Theory and Research,609-637, New York: Guilford.

Lee, E., \& Jang, Y. J. (2010). What do others' reactions to news on internet portal sites tell us? Effects of presentation format and readers' need for cognition on reality perception. Communication Research, 37(6), 825-846. doi: $10.1177 / 0093650210376189$

Luoma-aho, V. (2006). From stakeholders to faith-holders: Reputational advantage of frequent contact and high trust. Retrieved from http://research.jyu.fi/orgevolution/researchpapers/luamoahoICCRIIC06.pdf

Luoma-aho, V. (2009). Love, hate and surviving stakeholder emotions.Conference paper for the Public Relations Conference, Miami, FL, USA, March 11-14, 2009 http://www.instituteforpr.org/iprwp/wpcontent/uploads/Love_Hate.pdf

Luoma-aho, V. (2010). Emotional stakeholders: A threat to organizational legitimacy?Conference paper for the 60th Annual Conference of the International Communication Association, Singapore, June 2226.http://www.academia.edu/245892/Emotionalstakeholders.

Mason, A.M. (2014). The impact of media frames and treatment responsibility within the situational crisis communication theory framework, Corporate Reputation Review, 17, 78-90.

Mason, A.M. (2016). Media frames and crisis events: Understanding the impact on corporate reputations, responsibility attributions, and negative affect. International Journal of Business Communication. Published online May 16, 2016 doi:10.1177/2329488416648951.

Miller, C. H., (2016). Hedonic relevance and outcome relevant involvement. In D. K. Kim \& J. Dearing (Eds.) Health Communication Measures, 99-106, New York: Peter Lang.

Millner, A.G., Veil, S.R., \&Sellnow, T.L. (2011). Proxy communication in crisis response. Public Relations Review, 37(1), 74-76.

Ndlela, M.N. (2019). A Stakeholder Approach in Managing Reputation: A Stakeholder ApproachIn: Crisis Communication. Palgrave Pivot, Cham pg. 77-109. doi.org/10.1007/978-3-319-97256-5_5

Ortony, A.,Clore, G. L. \& Collins, A. (1988).The Cognitive Structure of Emotions. Cambridge: University Press.

Pang, A. (2013). Social media hype in times of crises: Nature, characteristics and impact on organizations. Asia Pacific Media Educator, 23(2), 309-336.

Pang, A., Hassan, B. B. B. A., \&Chong, A. C. Y. (2014). Negotiating crisis in the social media environment. Evolution of crises online, gaining credibilityoffline.Corporate Communications: An International Journal, 19(1), 96118. doi: 10.1108/CCIJ-09-2012-0064

Pang, A., Hassan, B., \&Chong, A.C. (2014). Negotiating crisis in the social media environment: Evolution of crises online, gaining credibility offline. Corporate Communications, 19(1), 96-118. doi:10.1108/CCIJ-09-20120064

Pavlou, P. A., \&Dimoka, A. (2006). The nature and role of feedback text comments in online marketplaces: Implications for trust building, price premiums, and seller differentiation. Information Systems Research, 17(4), 392-414. doi:10.1287/isre.1060.0106

Poindexter, P.M. (2012). Millenials, news and social media. Peter Lang, New York, NY.

Prochazka, F., Weber, P., \&Schweiger, W. (2016). Effects of civility and reasoning in user comments on perceived journalistic quality. Journalism Studies. http://doi.org/10.1080/1461670X.2016.1161497

Roseman, I.J. (1991). Appraisal determinants of discrete emotions. Cognition and Emotion, 5.

Santana, A. (2014). Virtuous or Vitriolic: The effect of anonymity on civility in online newspaper reader comment boards. Journalism Practice (8)1, 18-33. doi. 10.1080/17512786.2013.813194

Suler, J. (2004). The online disinhibition effect. Cyber Psychology \& Behavior. 7(3), 321-326. doi: $10.1089 / 1094931041291295$.

Shaver, K.G. (1985). The attribution of blame: Causality, responsibility, and blameworthiness, Springer-Verlag: New York.

Siah Ann Mei, J., Bansal, N., \& Pang, A. (2010). New media: A new medium in escalating crises? Corporate Communications: An International Journal, 15(2), 143-155. doi:10.1108/13563281011037919 
Springer, N. (2014). Smudged Public Sphere? Why people use the commentary function on online news pages as a public toilet wall, why visitors read the remains nevertheless, and how the walls look thereafter. Berlin: LIT.

Ulmer, R. R., Sellnow, T. L., \& Seeger, M. W. (2014). Effective crisis communication. Thousand Oaks, CA: Sage.

Utz, S., Schultz, F., \&Glocka, S. (2013). Crisis communication online: How medium, crisis type and emotions affected public reactions in the fukushimadaiichi nuclear disaster. Public Relations Review, 39(1), 40-46. doi:10.1016/j.pubrev.2012.09.010

Wang, R. \&Owyang, J. (2010). Social CRM: The new rules of relationship management. Retrieved from http://www.slideshare.net/jeremiah_owyang/social-crm-the-new-rules-of-relationship-management

Weber, P. (2014). Discussions in the comments section: Factors influencing participation and interactivity in online newspapers' reader comments. New Media \& Society, 16(6), 941-957.

Weiner, B. (1996). Searching for order in social motivation. Psychological Inquiry, 7, 197-214. Reprinted in Adair, J.G., Belanger, D., and Dion, K.L. (1998). (Eds.) Advances inPsychological Science, 93-109.

White, C., \& Raman, N. (1999). The world wide web as a public relations medium: The use of research, planning, and evaluation in web site development. Public Relations Review, 25(4), 405-419. doi:10.1016/S03638111(99)00027-2 


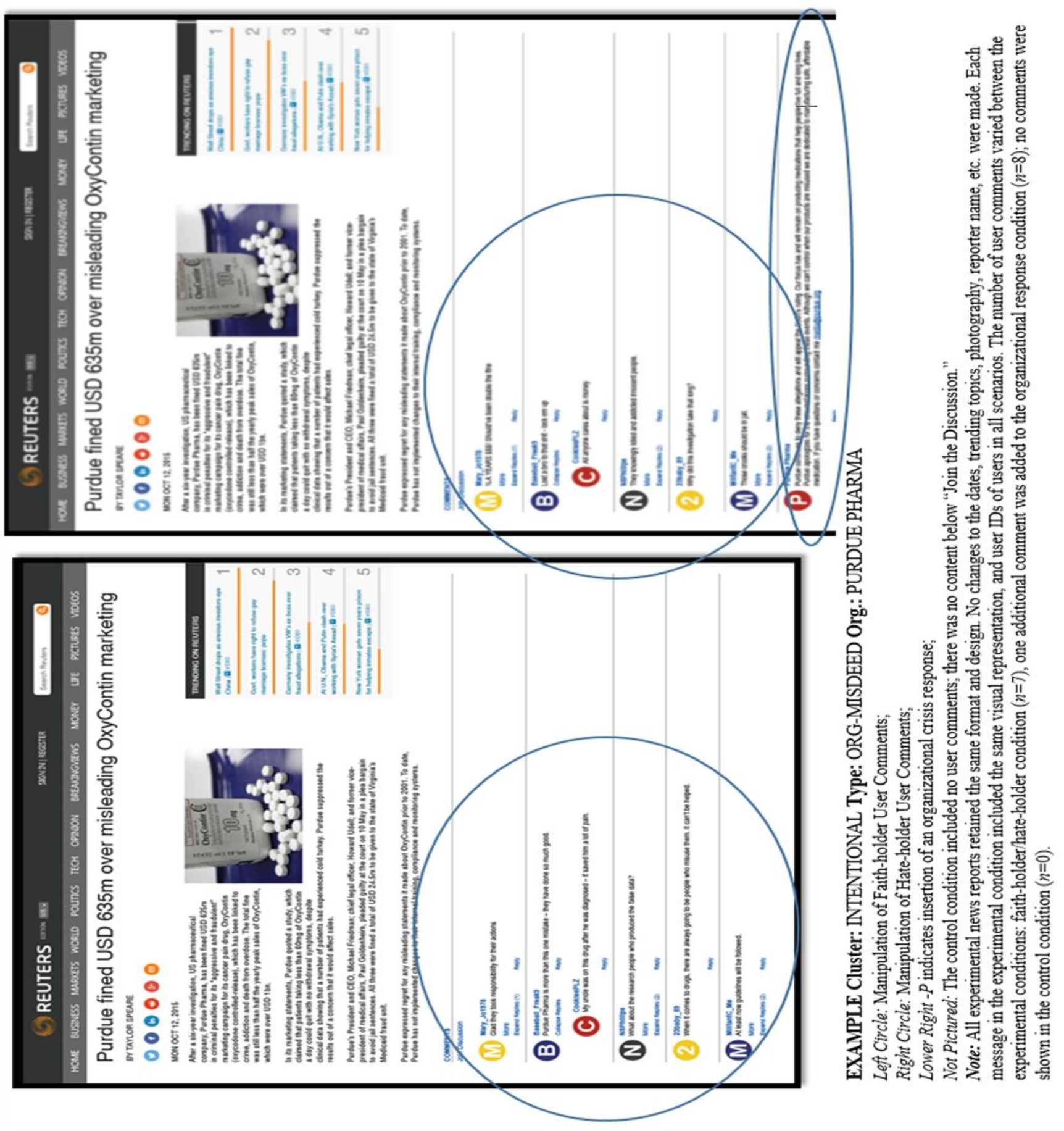

